\title{
Cell-based IQQM Wetland Modelling for Yanga National Park, a forested lowland floodplain in southern New South Wales
}

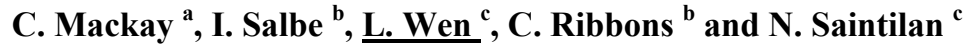 \\ ${ }^{a}$ Office of Water, NSW Department of Primary Industries; formerly SKM \\ ${ }^{b}$ Office of Water, NSW Department of Primary Industries \\ ${ }^{c}$ Office of Environment and Heritage, NSW Department of Premier and Cabinet \\ Email: Li.Wen@environment.nsw.gov.au
}

\begin{abstract}
Developing wetland hydrological models was an essential component of the NSW Rivers Environmental Restoration Program (RERP). The RERP aimed to arrest the decline of nationally important wetlands in the Murray-Darling Basin, and Decision Support Systems (DSS) have been developed for several wetland complexes to evaluate and compare the ecological impact of different river management policies, strategies and programmes. Each DSS is underpinned by a long-term hydrological model that provides inundation extents, volumes and durations for each wetland feature.

This paper details development of the Yanga National Park hydrological model that provides hydrology inputs to the Lowbidgee DSS. Model development followed a novel approach, combining the advantages of hydrodynamic and hydrological modelling. Hydrodynamic models such as MIKE21 are routinely used to simulate flood inundation for a range of environments and spatial scales. However, the hydrodynamic model computation time required to simulate an area as large as Yanga National Park over many years and for repeated scenarios makes it impractical to use such a model to provide direct inputs into a DSS. By comparison hydrological models such as IQQM generally take minutes to simulate long periods and allow wetlands to be integrated into broader valley-based water resource model systems.
\end{abstract}

Such hydrological models are normally developed and calibrated directly from observed hydrometric data. However, in the case of Yanga National Park very little hydrometric data was available, and a different approach was required. As an interim step in hydrological model development, a detailed hydrodynamic model was developed to provide insight into the floodplain hydraulics of Yanga National Park. Hydrodynamic model results were used to schematise and construct the hydrological model.

Hydrological model schematisation was established from the location of key wetland features identified on the ground, but also from the flowpaths and hydraulic controls identified by the hydrodynamic model simulations. This resulted in a total of 34 "cells" in the Yanga National Park hydrological model. For each of these cells simplified cell volume / inter-cell flow relationships were derived from the hydrodynamic model results. The hydrological model was then validated against inundation mapping based on satellite images between 1988 and 2006.

The validated IQQM model provides a range of inputs to the DSS, including inundation surface area, volume and water depth. It has been used to estimate actual historical wetland inundation patterns between 1975 and 2010, and to model wetland inundation patterns and durations for different Murrumbidgee River management scenarios for periods greater than 100 years. Further work is required to address uncertainty in modelling inundation extents due to infiltration and vegetation effects, and to validate the model further against recent flood inundation between December 2010 and February 2011.

Keywords: Environmental water delivery, hydrodynamic modelling, hydrological modelling 


\section{INTRODUCTION}

Yanga National Park forms part of the Lowbidgee Wetland Complex at the western end of the Murrumbidgee River. The Park covers an area of 80,000 ha and includes a number of different wetland features including significant River Red Gum Eucalyptus camaldulensis forests and woodlands, shrub-dominated wetlands, and seasonal freshwater lakes and marshes. Wetlands in the Park and the wider Lowbidgee area are renowned as critical fish and waterbird habitats and refuges for arid and semi-arid biodiversity (Maher 1990).

These ephemeral floodplain wetlands experienced highly variable patterns of high and low flows and water levels in their natural state. The subsequent development of the Lowbidgee for managed forestry and agriculture, and river regulation in the wider Murrumbidgee Valley, has seen significant changes in the extent and duration of flooding in the Park. River regulation has decreased the frequency and size of floods reaching the lower river (CSIRO, 2008), and inundation from overbank flooding is now supplemented by controlled inflows through river bank structures. These changes have led to an overall decrease in floodplain inundation extent, duration and frequency (Page et.al. 2005). Because inundation patterns are one of the fundamental drivers of the extent and type of ecology in the floodplain, these changes are altering the ecological characteristics of the Park.

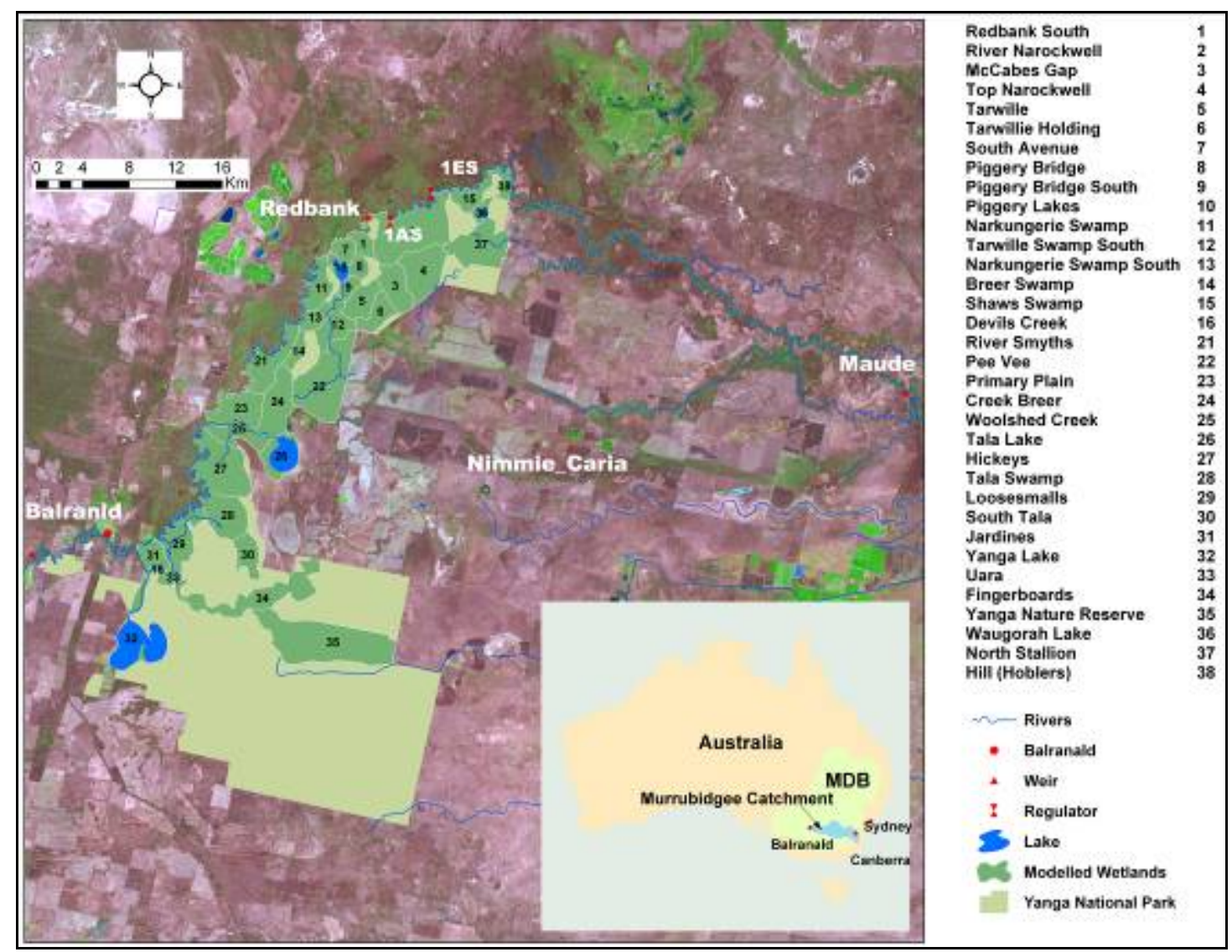

Figure 1. Yanga National Park in the Lowbidgee Floodplain

\section{METHODOLOGY}

\subsection{Overview}

In the absence of historical records, hydrological modelling can help to develop our understanding of the historical hydrological regime. A model provides a means to estimate historical flows and improves our understanding of the hydrology-ecology relationship, which is critical for the success of river environmental restoration. Furthermore, a hydrological model can be used to simulate wetland flooding patterns under different water resource management scenarios (e.g. environmental water applications) and climate scenarios. The outcomes of these scenarios can be fed into a Decision Support System (DSS) to predict the likely ecological impact of water management actions. 
However the construction, calibration and validation of hydrological models also rely on historical data being available. In the absence of adequate data, the inundation characteristics of the floodplain must be derived from other sources. In this project a detailed LiDAR based hydrodynamic model and inundation mapping derived from satellite imagery were used to provide information for the development of a hydrological model.

\subsection{Available Modelling Datasets}

Little hydrological data has been collected wihtin the Lowbidgee area, and there is only approximate knowledge of historical inflows into the system and the resulting inundation extent and duration this produced.

To progress this project a range of data was collected, including:

- Capture and development of LiDAR Digital Terrain and Elevation Models at 1 metre grid resolution

- Satellite imagery historical inundation extents (1988-2006) and vegetation mapping (Thomas et. al. 2010)

- Soil survey and mapping including several trial infiltration plots

In addition to these activities a number of hydrometric recorder stations were installed within the Park in 2008 to capture inundation events and allow direct validation of the hydrological model in the future.

\subsection{Hydrological Event Scale}

The hydrological model was developed to address a number of objectives. A key requirement for the model was that it simulated the full range of inflows experienced by the individual wetland features, whether this flow had been intentionally directed there, or arrived in an uncontrolled river flood.

Firstly, the model should be able to simulate the fate of water diverted through a river bank structure into the floodplain. This controlled inflow is typical of water set aside in upstream dams for environmental use, and it is diverted into the floodplain with the specific purpose of inundating a particular flowpath or wetland. The inflow is limited by the hydraulics of the intake structure, and the duration of inflow depends on the volume of water available and the objective of the watering. Such controlled inundation can reach lower lying wetlands and ephemeral lakes close to the river corridor, and the direction of flow is chiefly controlled by small-scale flood runners and depressions.

Secondly, the model should simulate the fate of water spilling uncontrolled into the floodplain over the river banks, as occurs when peak flows in the Murrumbidgee River at the Park exceed approximately 8,000 ML/d. The extent and duration of inundation in this type of event is unlimited and depends largely on the size and duration of the river flood. Smaller overbank floods may inundate only the immediate river corridor, while larger events can inundate areas tens of kilometres from the river channel. Finer floodplain features which are critical in directing inflows that have come through river bank gates have less influence on these larger uncontrolled events, and flood inundation is generally driven by broader scale topography.

\subsection{Modelling Approach}

This study used a novel approach of developing an IQQM hydrological model from a detailed MIKE21 twodimensional hydrodynamic model of the floodplain area. The grid-based hydrodynamic model was used to derive relationships between different parts of the floodplain, which are referred to in the hydrological model as cells. The overall process of developing the hydrological model was:

1. Development of a 2-D hydrodynamic model schematisation

2. Selection of a hydrodynamic grid spacing, grid review and editing

3. Hydrodynamic model set-up and calibration

4. Extraction of cell scale relationships from the hydrodynamic model for use in the hydrological model

5. Hydrological model schematisation and set-up

6. Validation of the hydrological model against the hydrodynamic model

7. Validation of the hydrological model against inundation mapping

\section{HYDRODYNAMIC MODEL DEVELOPMENT}

The primary purpose for the hydrodynamic model was to provide flow relationships underpinning the hydrological model. However, the hydrodynamic model may also be useful in the future for simulating shorter timescale events at a high level of detail, and for reviewing the hydraulics of specific measures such as construction of new structures and banks within Yanga National Park (SKM, 2010). 
Several key issues arose in development of the hydrodynamic model. Model grid scale is known to significantly affect inundation extent and flow travel times (Bates et.al., 2003). This affects the ability of the hydrological model to accurately simulate a wide range of flows including both smaller controlled diversions and large uncontrolled flood events. If the scale of the hydrodynamic model is too coarse, it will be unable to provide hydrological model cell relationships able to capture the movement of small flow volumes through finer scale floodplain runners and depressions.

A comparison of the impact of grid scale choice on flow between different parts of the floodplain is given in Figure 2, which shows two trial simulations with different computational grids. For the same volume of inflow, the finer scale (20 metre grid) model produces a more extensive inundation pattern than the coarser ( 80 metre grid) model. As a consequence, hydrological cell volume / flow relationships developed from the two grids will differ in the relative amount they distribute between cells.

Interdependence of grid scale and calibration is also noted. Trial grid scale simulations highlight that 2D model calibration is highly grid scale dependent, and calibrating to a given inundation pattern may not be possible for coarser grid sizes.

The improved resolution of floodplain runners in finer grid scale models is achieved at the cost of much longer simulation times. The grid scale selected is a compromise between sufficient detail to represent flow paths and a reasonable simulation

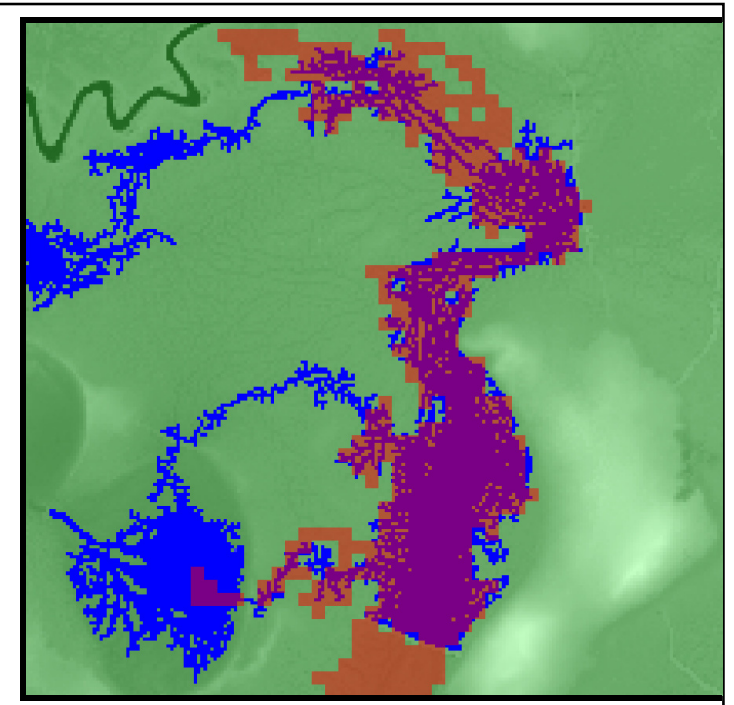

Figure 2. Comparison of inundation extent of equal volume simulations for 20 metre (blue) and 80 metre (red) grid resolutions time. The need for the hydrological model able to be applied to smaller flow rates diverted through river bank structures led to a 20 metre grid spacing being selected for this study.

Following preparation of the 20 metre DTM grid, a number of modifications were made to ensure key smaller scale features were adequately represented. A large number of man-made bank structures constructed specifically to redirect flows and key flowpaths were extracted from the 1 metre grid scale DTM, and maximum crest levels were applied to the corresponding 20 metre grid cell (SKM, 2010).

\section{HYDROLOGICAL MODEL DEVELOPMENT}

\subsection{Model Approach}

The hydrological model is based on the NSW Office of Water Integrated Quantity Quality Model (IQQM). IQQM has been used over the past 20 years to manage regulated river systems in NSW. It is capable of simulating long-term river system behaviour under various management scenarios (Hameed, 2001). It can simulate more than 100 years at daily scale within minutes and is an ideal tool to provide input to the DSS. The software used for this study is a variant of the IQQM software. It simulates the floodplain as a series of reservoirs or "cells", each of which has a level - area - volume curve. Flow between the cells is controlled by functions relating upstream cell volume to flow from the upstream cell into the downstream cell.

This IQQM variant was chosen for the hydrological model because in the future the Yanga National Park model will be merged with the existing Murrumbidgee River Valley IQQM model. Integration will allow direct testing of broader valley long-term water management scenarios on inundation patterns in Yanga National Park within a single model. This will make it more likely that the environment impacts of water management plans are considered more carefully in future.

\subsection{Model Development}

The operational management plan for Yanga National Park divides the Park into ten water management areas. However representing the Park at this level of detail in the hydrological model does not provide sufficiently detailed or accurate flow and inundation simulation results. In particular this level of modelling 
would not represent the hydraulic controls between different parts of the floodplain. Based on hydrodynamic model results the park was split up into the 38 hydrological model cells shown in Figure 1.

The hydrological model includes two types of curves, including level - area - volume derived from the DTM in GIS, and for water level - discharge derived from the hydrodynamic model. Water level - discharge boundaries were derived for all interfaces between hydrological cells, and between the cells and the Murrumbidgee River channel. Many cells have multiple inflows and outflows reflecting the interconnection of flowpaths in the floodplain and changing flow direction depending on the size and nature of inundation events. In some cases flow can pass in either direction between two cells depending on which cell receives flow first.

An example of the form of the water level - discharge functions derived is shown in Figure 3 for Cell 2 (River Narrockwell). Each function in the figure shows the water level required in Cell 2 to initiate flow into each of its adjacent cells, and the rate at which this discharge varies as the stored volume in Cell 2 changes. Comparison of the three curves shows how the outflow between the three adjacent cells is split for a given upstream Cell 2 volume.

External boundary conditions applied to the hydrological model include river inflow at the upstream (eastern) side of the model, floodplain inflow from the east, water level at the downstream

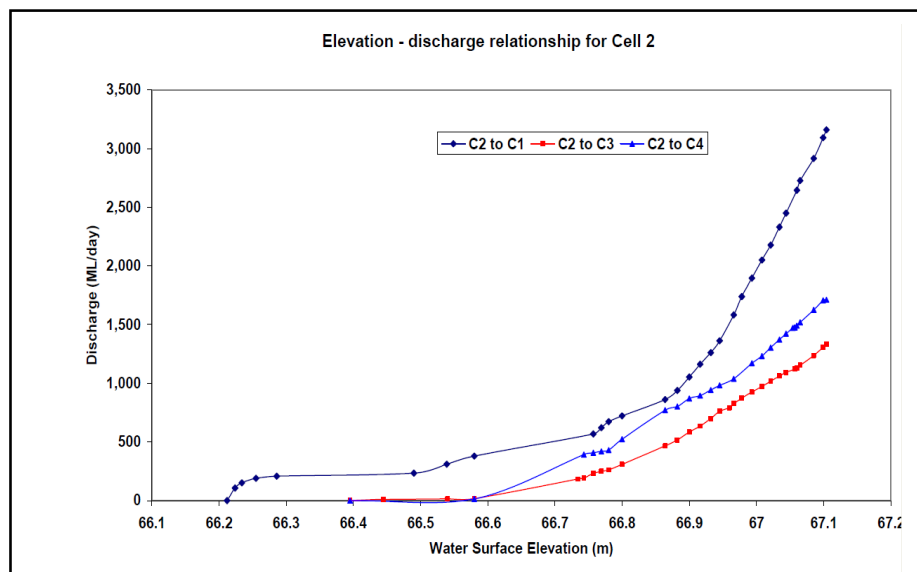

Figure 3. Example of cell water level (volume) - discharge outflow relationships (western) side of the model, time varying rainfall and evaporation from each cell based on measured meteorological data, and a steady-state soil infiltration rate.

\subsection{Hydrological Model Calibration}

No hydrometric level or flow records in Yanga National Park were available when the hydrology model was developed, and consequently the model could not be calibrated in a formal sense. Instead hydrological model volumes were compared against short-term (1-2 months) outputs from the hydrodynamic model. The objective of this comparison was to check that the combination of all the cell water level - discharge relations behaved in a similar way to the hydrodynamic model. As the water level - discharge relations were derived from the hydrodynamic model for each cell individually, it was important to check that when all cells were linked together they accurately simulated the overall distribution of flooding.

This was done using two sets of hydrodynamic model results to check flood arrival time and cell volume time series. The first being simulation of a steady discharge of $430 \mathrm{ML} /$ day into the floodplain through a gate in the river bank for two months, and the second being simulation of a large uncontrolled overbank flood event that inundated much of the floodplain. This is not a formal calibration as the data used to derive the water level - discharge relations is not independent of the inundation data used to check the overall model performance. However this process confirmed that the model was operating as expected, and that in almost all cases the cell water level - discharge curves agreed with the hydrodynamic data they were derived from.

In three cases the form of the hydrological model did limit its ability to reproduce hydrodynamic model behaviour. In these cases outflow from the cell area in the hydrodynamic model is affected by the water level in the floodplain downstream. As the hydrological model used can only represent one function between upstream water level and discharge into the downstream cell, it is unable to simulate the rate at which the cell area fills in the hydrodynamic model.

\subsection{Hydrological Model Validation}

Following calibration, the model was validated against 84 satellite inundation outlines derived for the period 1988 - 2006. The derivation of the outlines and their accuracy is given in Thomas et.al (2010). On the basis of comparison against aerial photography for one event, the accuracy of the mapping was considered high ( $80 \%$ agreement). The model was run continuously over this period of 1988-2006 and time series of 
inundated areas were extracted from the model results. These were then compared against the inundation outlines, and a Student's t-test applied to assess whether agreement between total inundated areas predicted by the model and the inundation outlines was significant. Overall, the model performance was acceptable. Modelled and remote sensing water areas are significantly related $\left(R^{2}=0.84, p<0.001\right.$, Figure 4$)$. However, the modelled total surface water area is significantly lower than the mapped inundation extent $(\mathrm{p}=0.0003)$, accounting for about $77 \%$ of the mapped value.

Figure 4 compares modelled (Y-axis) and satellite-derived (X-axis) flood extents from 1988 onwards. Most modeled values are below the $\mathrm{Y}=\mathrm{X}$ straight line (dashed line), illustrating that IQQM underestimated the flooded areas in most cases compared to inundation maps prepared from remote sensing data.

It was found that modelled results matched the inundation mapping better in wet years than dry years. Wet years were defined as being those where river flows upstream of Yanga exceed $8,000 \mathrm{ML} / \mathrm{d}$ for at least one day in the year, indicating some overbank flooding of the Park is likely to have occurred. In wet years, the modelled surface area accounted for about $79 \%$ of the total

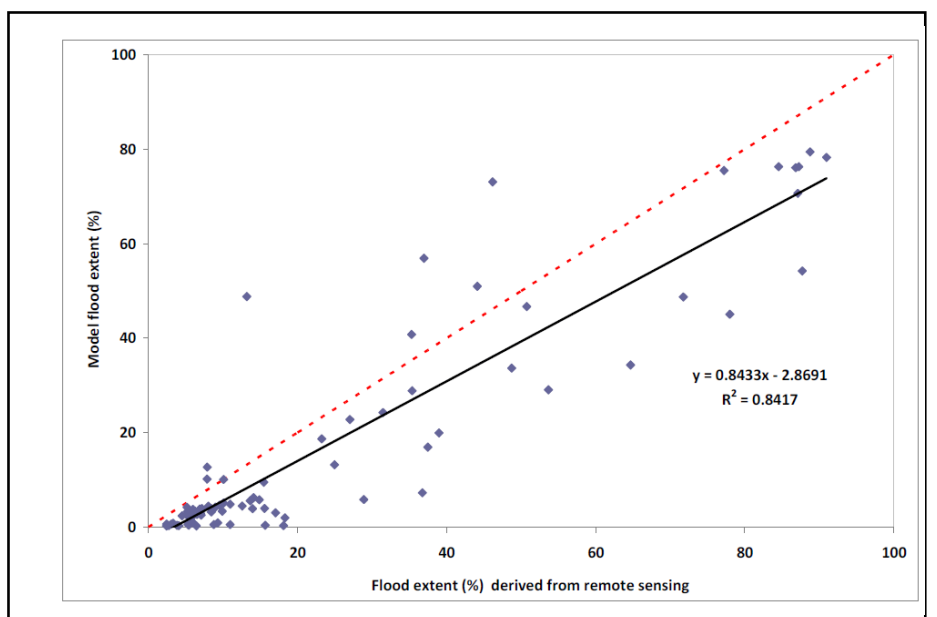

Figure 4. Comparison between modeled (Y-axis) and satellite-derived (X-axis) flood extent in Yanga National Park

mapped flooded area, while the model achieves only $44 \%$ during dry periods. In addition, the correlation between modelled and remote sensing values is much lower during dry periods $\left(\mathrm{R}^{2}\right.$ are 0.67 and 0.11 for wet and dry respectively).

Spatially, the model generally performed better for cells in the northern part of Yanga National Park, and tended to underestimate flooded area at the edge of the floodplain and in the southern part of the Park. Cells in this area receive flows relatively rarely, and primarily from the floodplain to the east (the Nimmie-Caria system) rather than directly from the Murrumbidgee River.

This location of cells with the greatest error, and the poorer performance in drier years, strongly suggests that the main limitation on model performance is the accuracy of controlled inflow time series through riverbank regulators, and in the eastern floodplain inflow boundary condition that introduces water through Tala Lake into the southern end of the Park. Historically, water entering from the eastern floodplain has been used to water the southern end of the Park however this has never been measured. In addition, the locations of banks and structures within the Park has changed between 1988 and the present day. As the distribution of flow within the Park is controlled by a number of artificial banks and gates, a single model simulation with current banks and gates may not reproduce observed inundation produced by configurations.

\section{HYDROLOGICAL MODEL RESULTS}

The Yanga National Park cell-based IQQM hydrological model was used to simulate wetland inundation under different river flow scenarios. Two of these scenarios were:

- Estimated pre-development river flows: River hydrograph boundary conditions to the hydrological model derived from a Murrumbidgee Valley-wide IQQM model that simulates what historical river would have been in the absence of upstream storages and water extraction for irrigation and other uses

- Actual river flows: River hydrograph boundary conditions are recorded river flows upstream of the Park for the period 1974-2009

The simulated actual total inundation area is substantially less than inundation in pre-development conditions (Figure 5). The magnitude of reduction decreases with percentile indicating development has produced a greater relative reduction in inundation extent in drier years. During drought, more river flow (in terms of proportion) is diverted for human use upstream resulting in much less water entering Yanga. During wetter periods less floodwater is diverted for use upstream as upstream dams are fuller and the ability to use additional water is limited. 
The reduction in inundation extents between the pre-development and actual inundation scenarios is consistent for all cells across Yanga National Park, although the magnitude of reduction varies. A general pattern is that the reduction is greater for open water lakes than for forested swamps.

In addition, the magnitude of reduction was lower for cells located downstream of Tala Lake and further away from the Murrumbidgee River (e.g. South Tala and Yanga Natural Reserve). These cells are at the edges of the floodplain and would have received water during rarer larger flood events under pre-development conditions. River regulation has had a greater relative impact on small-medium size floods than

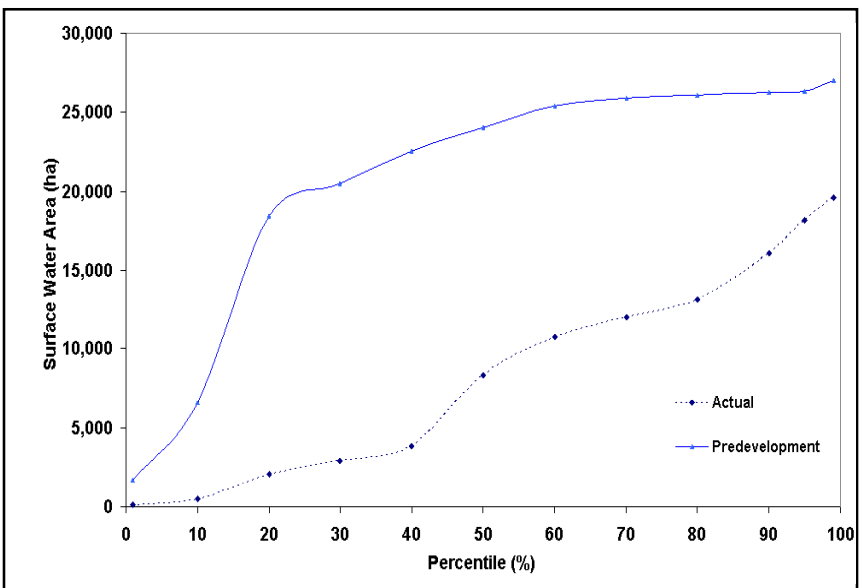

Figure 5. Comparison of modeled surface water areas percentile (less than) under actual and predevelopment larger floods (CSIRO, 2008), and this may explain why those cells only inundated by larger floods show a smaller inundation reduction between pre-development and actual scenarios.

\section{DISCUSSION AND CONCLUSIONS}

A detailed hydrological model of Yanga National Park has been developed to support the Lowbidgee DSS. In the absence of hydrometric data hydrological model development has relied on fine scale hydrodynamic modeling and satellite based inundation mapping. Validation confirms the hydrological model reproduces the behavior of the hydrodynamic model and some aspects of historical inundation patterns. The model reproduces inundation in the northern part of the Park well, however it underestimates inundation in the southern Park downstream of Tala Lake. This reflects the historical uncertainty in inflows from the eastern floodplain used in simulations.

Further validation is required against hydrometric data from the recent 2010 - 2011 environmental water releases and floods. Improved flow monitoring at the model boundaries will reduce the uncertainty in model volumes. Furthermore, observations of smaller inflow volumes and resulting inundation extents may allow improvements to infiltration modeling in the future.

\section{ACKNOWLEDGMENTS}

This project was funded through the Rivers Environmental Restoration Program (RERP) which is supported by the NSW Government and the Australian Government's Water for the Future - Water Smart Australia Program. RERP aims to arrest the decline of wetlands through water recovery, effective management of environmental water and the sustainable management of our wetlands.

\section{REFERENCES}

Bates, P.D., Marks, K.J., Horritt, M.S., (2003). Optimal use of high-resolution topographic data in flood inundation models. Hydrol. Process. 17, 537-557.

CSIRO (2008). Water availability in the Murrumbidgee. A report to the Australian Government from the CSIRO Murray-Darling Basin Sustainable Yields Project. CSIRO, Australia.

Hameed, T. and G. Podger, (2001). Use of IQQM simulation model for planning and management of a regulated river system, IAHS Red Book 2001, 83-89.

Maher, P. (1990) Bird Survey of the Lachlan/Murrumbidgee Confluence Wetlands. NSW National Parks and Wildlife Service: Hurstville, NSW.

Page, K., Read, A., Frazier, P., Mount, N., (2005). The effect of alternated flow regime on the frequency and duration of bankfull discharge: Murrumbidgee River, Australia. River Research and Application 21, 1-12.

SKM, (2010). Hydrodynamic Modelling of Lowbidgee Redbank Wetlands. Final report prepared for NSW Department of Environment, Climate Change and Water.

Thomas, R. F., Lu, Y., Cox, S. J. and Hunter, S. J. (2010). Inundation mapping and monitoring of Lowbidgee Wetlands. Final RERP Report. NSW Department of Environment, Climate Change and Water: Sydney. 